\title{
The Role of Saving and Lending Cooperatives in Increasing Its Members Earning and Review Based On Islamic Law
}

\author{
Fathul Djannah $^{1}$, Muhammad Rizal ${ }^{2}$ \\ ${ }^{1}$ Universitas Panca Budi Medan \\ ${ }^{2}$ Universitas Islam Negeri Sumatera Utara \\ djannahf@gmail.com
}

\begin{abstract}
The papers aim is to conformity with the content and spirit of the 1945 constitution, the government of the Republic Indonesia has underlined that cooperative ventures will be the pillar and accommodation of the people's economy. A descriptive and analytic study has been conducted through the collection the data from interviews and completed questioners of the purposive sampling method. The study has reveals the services of saving and lending cooperatives to their members as well as the community are still unsatisfactory, but it has some benefit to the members. The money saving and lending contracts can be classed as reciprocal and contain the principles of freedom to contract and equilibrium. The cooperative principles are relevant with Islamic Law. It stills no consensus in opinion among the Moslem Scholars on the rate interest in money saving and lending from the cooperative.
\end{abstract}

Keywords: Co-operative; principle of freedom contract; Islamic Law

\section{Introduction}

Savings and loan cooperatives are the pillars of the Indonesian economic system, and are one of the economic actors, which is working together with other economic actors, namely State-Owned Enterprises and Private-Owned Enterprises. Striving to realize a just and prosperous society. In realizing and developing economic democracy, the economic actors mentioned above must really be built in accordance with article 33 paragraph (1) of the 1945 Constitution. The success of cooperative organizations will be the key to national economic resilience of the Indonesian nation, but in reality the cooperatives / savings and credit cooperatives appear more lagging compared to private businesses and state-owned enterprises.

Savings and credit cooperatives function as one of the arteries of the Indonesian economy, is a business entity that struggles in the economic field, with the aim of improving the welfare of its members and the community. In order to increase the role of savings and loan cooperatives in national economic life, cooperatives need to be more socialized so that they can grow and develop as a movement of the community itself. As a people's economic movement, development needs to continue to be encouraged so that it can become an independent people's economic institution and its growth is rooted in society, and is able to become a major in the economic life of the Indonesian people. The Muslim community is the largest population in Indonesia, especially in the city of Medan, the development of cooperatives by the Islamic community is very potential, because the principles of cooperatives are very relevant to Islamic teachings.

Proper development of savings and loan cooperatives needs to be intensified so that they can grow and develop in a healthy manner and the results of their efforts are increasingly enjoyed by their members. Savings and loan business is an old-age business, which is run by cooperatives in Indonesia, both in multi-purpose or single-purpose cooperatives. In savings and loan cooperatives people are educated to save regularly. The members of the cooperative 
hope that from the savings they can borrow money, to meet some of their needs, both for business capital or other needs, which are expected to increase income.

In serving the loan request, the savings and loan cooperative serves the demands of members or the surrounding community, the savings and loan cooperative holds a savings and loan agreement. The agreement is a legal relationship, which contains several aspects of law. These aspects of law can support the guarantee of the rights and obligations of each party. The guaranteed rights and obligations of the parties is one of the determining factors in the development of cooperatives, because it means that the cooperative can serve the needs of its members as expected. This has encouraged the author to make research to answer the problem, how the role of savings and loan cooperatives in increasing the income of its members, whether the role of savings and loan cooperatives is supported by legal aspects related to savings and loan agreements, including:

Who and how are the terms of the parties bound in the savings and loan agreement, what is the basis of the legal relations of the parties, what are the rights and obligations of the parties arising from the agreement, how to resolve it if there is a dispute between the parties, what factors constitute constraints in the development of savings and loan cooperatives and Islamic views about savings and loan cooperatives.

\section{Review of Literature}

\subsection{Cooperative and Its Existence}

Law No.12 of 1967 in article 3 states: "Indonesian cooperatives are social economic organizations with a social character, consisting of people, or cooperative legal entities which constitute an economic arrangement as a joint effort based on the principle of kinship". In the memory of the explanation of Article 3, I have stated, Indonesian cooperatives are a collection of people who work together, work together based on equality, work to advance the economic interests of their members and the interests of society.

International labor organizations provide the following definitions of cooperatives:

"... Cooperative is an association of persons, usually of limited means, who has voluntary joined together to achieve a common economic end through the formation of democratically controlled business organizations; making equitable contribution to the capital required and accepting a fair share of risks and benefits of the understanding "(Department of Cooperatives Director of Counseling Counseling, 1983; 9).

Mohammmad Hatta, in his book: The Cooperative Movement in Indonesia said: "Cooperatives are a joint effort to improve the lot of economic livelihoods based on helping. The cooperative movement is a symbol of hope for the weak economy, based on self-help and help to help among its members, which gives birth to among them self-confidence and brotherhood. Cooperative embodies a new universe, a spirit of self-help, driven by the desire to provide services to friends based on, one for all and all for one, this is called "auto activity group" (Department of Cooperatives, Directorate of Counseling Counseling, 1983: 19). Cooperatives in Indonesia already have a definite place, because they already have their own laws. The cornerstone of the Cooperative is:

1. Idiil Foundation

2. Constitutional foundation

3. Operating Foundation. 
The Idiil of the cooperative is Pancasila. The foundation is none other than Pancasila because the foundation of the Republic of Indonesia is the Pancasila. Pancasila is the philosophy of the Republic of Indonesia, which serves as a guide for the lives of all Indonesian people, therefore the five precepts of Pancasila must form the basis of the Indonesian Cooperative.

The constitutional basis, in Indonesia, the life order in the State is regulated in the 1945 Constitution. Therefore the constitutional basis of Indonesian cooperatives is the 1945 Constitution, Article 33 paragraph (1). From the explanation above, the foundation of constitutional cooperatives in Indonesia can be said to be very strong, the provisions contained in the 1945 Constitution must be implemented consistently.

The operational basis is;

1. MPR Decree No.1 II / MPR / 1988 concerning GBHN.

2. Law No.12 of 1967 concerning Cooperative Principles.

3. Basic Basis and Cooperative Bylaws.

a. In the section on the direction of general development policy number 28, it states: "... Furthermore, it is necessary to create a healthy business climate and a relationship system that encourages the growth of conditions of mutual support between State businesses, cooperative businesses and private businesses, as well as mutually beneficial and fair linkages between strong economic group and weak economic group: ".

b. "... especially the Village Unit Cooperatives need to be increased in their role in life, socio-economic community, especially in rural areas. In line with that, it is also necessary to continue to improve the abilities and roles of functional cooperatives, such as cooperatives of company employees, civil servants, women, youth and students to grow stronger " (MPR Stipulation, 1988: 63)

c. Law 12 of 1967, is an organization of social economic community organizations with a social character and as a means of democratizing the national economy, this law reflects the soul and ideals contained in the 1945 Constitution Article 33 paragraph 1 and his explanation as the mandate of the suffering of the Indonesian people.

d. "Cooperative statutes and by-laws." Articles of association are all rules that directly regulate cooperative life and relationships between cooperatives and their members "(Hans H. Munkner Abdul Abdul Kadir Muhammmad, 1987: 40).

To set up a cooperative, there must be a b-person who is interested in being a pioneer of the members called the founder. The government is obliged to provide guidance, supervision, protection, and facilities to cooperatives. Means the government intervened in the procedures for establishing cooperatives. Cooperatives whose establishment deed is validated according to the provisions of the Cooperative Law are Legal Entities (Law no. 12 of 1967, article 41) the government gives legal entity status with the aim that cooperative so that cooperatives can easily say legal relations with third parties.

\subsection{Definition and Role of Savings and Credit Cooperatives.}

Law No. 12 of 1967 did not make a formula about the definition of Savings and Credit Cooperatives. Some definitions of savings and loan cooperatives:

1. Savings and loan cooperatives are "Cooperatives engaged in the field of capital formation through the savings of members regularly and continuously to then lend to 
members in an easy, inexpensive, fast and appropriate way for productive and welfare purposes" (Ninik Widiyanti, YW Sumindhia 1989: 54).

2. "Savings and Loans Cooperatives are cooperatives whose members, everyone has a direct interest in the field of credit with the business field accepting deposits, providing capital loans to members who need capital on easy terms and low interest" (Chaniago, 1987: 1) .

3. Savings and Loans Cooperatives are: "A group of people in a unifying union who jointly agree to save their money so as to create joint capital, which can then be lent among their peers with light interest for productive or welfare purposes". (T. Gilarso 1976: 112).

In a cooperative there are generally activities or savings and loan businesses. Savings and loans are carried out either in a cooperative business that is a single business or is part of a multi-business cooperative or is a unit of the activities of a cooperative. As described above, the type of cooperative activity is carried out and determined based on mutual agreement between members. Cooperative and its management. Savings and loan cooperatives try to meet the credit needs of their members by saving (saving first). A member can be fulfilled his credit request, if the member already has his savings / savings, then in fact it is more appropriate to be called a savings and loan cooperative. But sometimes it is called a credit cooperative because it is given the opportunity to its members to get a loan or credit easily and low interest. Guidance and supervision of savings and loan cooperatives (KSP), and savings and loan cooperatives of the Village Unit through member groups, are aimed at preventing service practices to non-members and the dominance of individual capital used for loan services for personal gain.

Cooperatives that seek credit, among others, savings and loan cooperatives, bank cooperatives, multi-business cooperatives, village unit cooperatives, employee cooperatives and others. Functional cooperatives at the beginning of their growth are also cooperatives engaged in credit. Agreements or agreements contained in cooperatives are held in accordance with the cooperative's business activities carried out. In the savings and loan cooperative, the activities carried out are holding money storage and money lending. Then the agreement or agreement carried out is an agreement on saving money and borrowing money between the savings and loan cooperative with another party. In article 1313 of the Civil Code it is stated that "An agreement is an act by which one or more commit themselves to one other person or more".

In a savings and loan cooperative the parties that enter into an agreement (agreement), that is, one party is a savings and credit cooperative the other party is the members. Sometimes there are other parties (third parties) who are not members of the savings and loan cooperative, namely government and private financial institutions, money-lenders individuals and community members.

According to article 1320 of the Civil Code (BW), for an agreement to be valid, several conditions are required:

a. Agree those who bind him.

b. The ability to make an engagement.

c. A certain thing.

d. A lawful cause. 


\subsection{Savings and Credit Cooperatives according to Islamic Teachings.}

In the time of the Prophet Muhammmad S.A.W. Islam shows a way out about the system of using capital owned by certain people. That system is the Syirkah system. Syirkah means cooperation. "Syiran means mixing" (Said Sabiq, 1973: 178). The Fuqaha members formulated that Syirr is a contract between two or more people who share about capital and profits. Al-Qur'an and hadith are the source of all law, in relation to aspects of human life, including the problem of cooperatives or syirkah in terms of Islamic law.

In essence the Syirkah system is an Islamic economic system recommended by the Prophet Muhammad S.A.W. The cooperative system has many similarities with the Syirkah system (H. Masngudi, 1989: 8). One thing that cannot be denied is, in essence the principle of cooperatives is very much in accordance with Islamic teachings, reflected in the Al-Maidah verse (2), and the An-Nisa verse (85). (Ministry of Religion of the Republic of Indonesia S.5: 2 and S.4: 85). Surat ash-shuura verse 29, letter Ali-Imran verse 159, is very relevant to the basic joints of cooperatives, which among others state: Members' meeting is the highest power, as a democracy in cooperatives ... according to the Fuqaha, Syirkah is divided into 3:

a. Syirkah abdan.

b. Syirkah Mufawadhah.

c. Wirk Syirkah and Syirkah Inan.

The new syirkah that has not been known by the Fuqaha before is Syirkah Ta'Awuniyah. (Mahmud Syalthot, 1966: 9) Ijma Ulama, Syirkah (cooperatives) do not contradict Islamic teachings. (Sayid Sabiq, 1973: 506). Shirkah in Islam is one of the Muamalah systems that are useful in efforts to improve the standard of living of humans and are favored / blessed by Allah.

From the formulation of the Savings and Loan Cooperative, expressly stated the existence of interest, even though the interest is mild. Mohammad. Hatta in his book several economic chapters stated that there were our scholars who frankly forbade rent with no member of the slightest freedom, and some scholars said that collecting fees or interest was indeed a bad job, but if the progress of the community wanted it, the rent or interest was allowed. In this case the nature of the law in Islam considers the bad well. If there is more good than bad, the law, must. This work is allowed. Furthermore, "there are Ulama who say that collecting flowers is permitted, if it is done in a straightforward manner and the tariff is stated (Fuad Mohd.Fachruddin, tt: 11). So that people will borrow can consider whether the loan is profitable for him or not. Is rent or interest the same as usury? Usury (urury or interest in English), derived from Arabic, means additional (ziyadah in Arabic) (addition in English) which means additional payments on the principal amount of the loan.

\section{Research Method}

Research location in the city of Medan. Primary data is data obtained from savings and loan cooperatives and respondents (32 cooperative management and 40 cooperative members taken by purposive sampling). Secondary data are from the North Sumatra Province Regional Cooperative Department and the Medan Municipality Second Level Cooperative Department. Research tools are guidelines for interviews, questionnaires and literature studies. 


\section{Research Method}

\subsection{Savings and Credit Cooperative and Its Role}

The role of Savings and Loans Cooperatives, carrying out business activities of saving (saving) and providing loans (credit), its purpose is mainly to increase the income of its members and the welfare of the community in general. In carrying out its business, working capital is needed. Law No.12 of 1967 in article 32 paragraph 1 stated: "Cooperative capital consists and is fostered from deposits, loans, and allowances from the results of their business including reserves and other sources". The initial capital (base) which is collected from the principal savings, mandatory savings and allowance for the results of its business is relatively small, so that it cannot serve the loan requests of its members. So to expand the space for serving loan requests, the cooperative must try to increase capital from outside (borrowing from a Government Bank or releasing individual money). Facilities / assistance from the government to get guarantees from the Cooperative Financial Development Corporation (PPKK), only given to certain cooperatives, members and non-members have no interest in saving voluntarily in savings and loan cooperatives. That was caused by, among others, the lack of trust of members and non-members to save money in the Savings and Loan Cooperative, the lack of appeal given to depositors. the awareness of cooperatives has not yet been planted in most members of the community, the administration of Cooperative Savings and Loans that has not been ordered. Loans given to members and non-members can be said to be unsatisfactory, but the benefits can be felt by members.

In fact, the Savings and Loan Cooperative still needs guidance and guidance from the Cooperative Department, especially in terms of management, capital and supervision so that the Cooperative can grow and develop. Government intervention does not mean that the Government is involved in determining and regulating the internal affairs of a Cooperative.

\subsection{Agreement on Savings and Loans Cooperatives}

The agreements contained in the Savings and Loan Cooperative is:

a. Agreement between the members and the Credit Savings and Credit Cooperative as the depository and lending money.

b. An agreement between a Savings and Loan Cooperative and members, in this case the members as the party who receives the money loan and who saves the money.

c. An agreement between a Savings and Loan Cooperative with a third party (Government Bank, individual remittance, community).

Basically the agreements in the Savings and Loan Cooperative are;

a. Save money agreement

b. Money lending agreement

Savings money agreement is a preliminary agreement of a loan agreement, this is a special feature of the agreement in the Savings and Loan Cooperative, the object agreement in this agreement is in the form of money. This agreement is classified as a mixed agreement (sui generis).

The principles contained in this agreement are:

a. The principle of freedom of contract all agreements. All agreements made legally apply as a law for the parties.

b. The principle of consensus is the agreement of the parties to bind themselves to one another. 
c. The principle of balance between the parties can mutually demand what has been promised.

d. Principle of legal certainty. The agreement made by the parties applies as law.

e. Principle of propriety and habit. This can be reflected in the basic joints and cooperative principles

Agreements with Savings and Loans cooperatives are agreements that fulfill the terms of the agreement according to the Civil Code. According to Article 1320 of the Civil Code, for the validity of the agreements required 4 Conditions:

1. Agree those who themselves.

2. The ability to make an engagement.

3. A certain thing

4. A lawful cause.

The promise of injury to the Savings and Loan cooperative was very small, and it was not brought to trial, but was settled internally, in accordance with the provisions of the cooperative. Based on the principle of kinship, togetherness and solidarity in cooperatives, it must be resolved as much as possible by the cooperative itself.

\subsection{Role and Development of Savings and Credit Cooperatives according to Islamic Law}

Islam teaches how humans manage their lives both in social and economic matters. Savings and Credit Cooperatives are one of the legal subjects that play a role in the social field. The terms of the agreement in the Savings and Loan Cooperative are included and fulfill the terms of the agreement (contract) in Islamic law. The problem that arises, is the agreement in the savings and loan business to the cooperative about services (interest) not in conflict with Islamic law? Are savings and loan services (interest) in a cooperative the same as usury?

From the role of the Savings and Loan Cooperative it can be seen that the savings are from members and loans are also given to members. Savings and Loans Cooperatives are the property of its members, so in determining the existence of services (interest), it will not burden and blackmail Savings and Loans Cooperative itself. In carrying out the business, the cooperative takes into account the remaining business results obtained in every one financial year, which are also distributed to its members (according to service comparisons). The services (interest) of a Bank are not the same as services (interest) in a Savings and Loan Cooperative. However, there has not been an agreement among the Ulama regarding savings and loan services (interest). The role of savings and loan cooperatives can be further developed by developing a concept that is closer to Islamic Sharia and economic realities. Savings and Loans Cooperatives can develop better if there is support from the community, especially the Islamic community which is the largest part of the population of Medan municipality, if the community understands that the Impan Koperasi Cooperative brings benefits to itself and the community and its business is not in conflict with Islamic Sharia.

The key to developing savings and loan cooperatives by Muslims depends on how far Muslims want and are able to utilize cooperative institutions. 


\section{Conclusion}

The role of savings and loan cooperatives in serving the loan needs of its members can be said to be unsatisfactory, but most members feel the benefits of a Savings and Loan Cooperative, which can indirectly increase the income of their members. Savings and loan agreements have special features, namely; Money saving agreements are preliminary agreements of credit (loan) agreements, classified as mixed agreements (sui generis) and reciprocity. The principles contained in the principles of freedom of contract, principle of balance, principle of propriety and habit.

Lack of community trust in savings and loan cooperatives. However, several verses of the Qur'an and the Hadith, Ijma Ulama, state that the principles of cooperatives are relevant to the teachings of Islam.

\section{References}

Al - Gazali , Muhammad, (1971), Al-mustashfa Minal Ilmi Usul , Mesir , Maktabah AlJummah.

Al - Haitami , Hajar ,Ibnu, Tuhfatul Muhtaj, Darul Sharir,t.t.

Al - Jaziri, Rahman ,Abdur , Al- Fiqhu Ala mazahibit Arba'ah Mesir.At-Tijariyah, t.t.

As - Suyuty, Jalalludin, (1976), Al- Jamiush Shaqir Darul Khatib, Al -Tijariyah, t,t.

Badrulzaman, Mariam,Darus, (1989), Perjanjian Kredit Bank, Bandung.

Bin Al - Buchary ,Ismail, Muhammad, Matan Buchary, Mesir, An-Nasiriyah, t.t.

Bin Hanbal, Ahmad, Musanad Imam Ahmad, Beirut, Maktabah Al- Islam, t.t.

Chaniago, Arifinal , (1979), Perkoperasian Indonesia, Bandung ,Angkasa.

Daud, Abu , Sunan Abu Daud, Mesir Matba'ah At - Tijariyah,t.t.

Fachruddin , Moch. Fuad, Riba Dalam Bank Koperasi, Perseroan dan Asuransi, AlMa'arif,t.t.

Fikri ,Ali Said, Ali Said, Al-Muamalah Al-madiyah Wal Adabiyah, Kairo, Mustafa AlHabil,t.t.

Gilarso, T, (1976), Dunia Ekonomi Kita, Yayasan Kanisius, Yogyakarta.

Kartasapoetra,G,et.al (1987), Koperasi Indonesia yang Berdasarkan Pancasila, P.T. Bina Aksara.

Sabiq, Said , (1973), Fiqhus Sunnah, Darul Fiksi, Beirut..

Subekti , (1979), Hukum Perjanjian, Intermasa, Jakarta.

Zain , Mohammmad,Sutan, Kamus Modren Bahasa Indonesia, Grafica, Jakarta, t.t.

Zuhdi, Masyfuk, (1989), Masail Fiqkiyah, C.V. H.Mas Agung, Jakarta. 